\section{Technical Assistance Programmes}

At the request of the International Co-operation Administration, the U.S. National Academy of Sciences--National Research Council has undertaken a study of the ways in which science and technology can most effectively be used by the Administration in its assistance programmes for Africa south of the Sahara and north of the Union of South Africa. Leaders in scientific and technological research and African studies have been asked to assist in the evaluation of opportunities for the utilization of research in the fields of public health, medicine, agriculture, natural resources, engineering and education. A final report will be submitted by June 1959. Dr. J. George Harrar, director for agriculture at the Rockefeller Foundation, has been appointed executive director of the study.

\section{Laboratory Equipment in American Schools}

Teachers of science in American colleges, universities and non-profit-making organizations have been invited by the National Science Foundation to submit proposals for the construction of better laboratory equipment for use in schools. Under the terms of a new, experimental programme, the Foundation will consider proposals for the design and construction of improved laboratory equipment and for the development of new instructional materials for lecture demonstrations, laboratory and field work for courses at elementary and secondary school, and undergraduate levels in mathematies, astronomy, earth sciences, physical and biological sciences, and engineering. Support will not be provided for the purchase of equipment for renovating school and college laboratories, or for commercial production of equipment or materials.

\section{Nigeria Science Association}

As a result of the rapidly increasing volume of scientific work in Nigeria, many scientists have for some time felt the need for a Nigeria Science Association. In October 1957 a meeting was called at the University College, Ibadan, to discuss the matter. After a further meeting in January 1958 it was decided that a Science Association of Nigeria should be formed and should hold its inaugural meeting in December 1958. A steering committee was elected, with Prof. J. Grayson, professor of physiology at University College, Ibadan, as chairman, and Dr. Brian Hopkins, lecturer in agricultural botany at University College, Ibadan, as secretary. The inaugural meeting of the new Association was held at University College, Ibadan, during December I519, 1958. At a brief but impressive opening ceremony, which was well attended, the Association was inaugurated by the Hon. Victor Mukete, Federal Minister for Research and Information. The opening ceremony was followed by a conference lasting four days. The first three days were devoted to papers and discussions of general interest and to business meetings, and the last day to specialist sections. Four specialist sections were organized : medical sciences, physical sciences, botany and zoology. At the business meeting, Dr. Eni Njoku, Department of Botany, University College, Ibadan, was elected first president, and Dr. Hopkins secretary. It is hoped that the next conference will be held in Zaria in December 1959.

\section{Frederick Soddy Trust.}

THE first report of the Frederick Soddy Trust (pp. 16. From the Frederick Soddy Trust, 9 The
Drive, Hove 3, 1958) includes a full record of grants made up to September 1958 as well as a list of rejected applications, with the view of indicating the principles used in selection. Emphasis is placed on team-work rather than individual work, and on actual study and research in the field. Some details are given of the survey of crofting in South Uist and Benbecula made in 1957; of the proposed study of Corby and of a survey of the parish of Ardington, Berkshire, proposed by the University of Reading; and also of an expedition to the Pyrénées in which a study is to be made of peasant agriculture and its response to a mountain environment; an attempt is to be made to evaluate the extent of possible population movement in the area.

\section{Smoke Control}

UNDER the title "Smoke is Your Enemy" (pp. 8, 1959) the Ministry of Housing and Local Government and the Central Office of Information have prepared a short pamphlet for issue to householders in areas which local councils are proposing to make smoke control areas. The pamphlet explains simply what smoke control will mean to the household, the grants available to the householder and the advantages which smoke control will bring.

\section{Exhibition of German Measuring Equipment}

As exhibition of precision measuring equipment, made by Carl Zeiss (Oberkochen) and by M. Hensoldt and Soehne (Wetzlar) and mainly of interest to those working in the fields of engineering metrology and metallurgy, was held during March 9-14, in the showrooms of Degenhardt and Co., Ltd., at 6 Cavendish Square, London. Although the equipment displayed consisted mainly of new versions of wellknown measuring and observing instruments, their new look made careful scrutiny necessary in some instances before identification with one or other of their famous prototypes could be made. In general, no claims were advanced for enhanced accuracy of performance over previous attainments, but outstanding improvements have been made in such matters as ease of manipulation of controls and adjustments. These new features considerably reduce the strain of continuous observing and contribute to the readier achievement by the user of the full potentialities of accuracy available in well-designed instruments. Ease of control was especially noticeable in the microscopes, of which the 'Ultraphot' camera microscope and the smaller Zeiss photomicroscope are typical examples; in addition, each is provided with a built-in automatic camera, and exposure time is regulated photoelectrically. The 'Technoscope', a binocular low-power microscope giving five different magnifications for the same working distance, has applications in the laboratory, the engineering workshop and the operating theatre. The range of engineering metrology equipment included the universal, tool-makers', interference and light-section mieroscopes, optical dividing heads, rotary dividing tables, alignment telescopes and a number of smaller measuring aids and devices.

\section{Organization for European Economic Co-operation Courses on Nuclear Science}

The European Nuclear Energy Agency of the Organization for European Economic Co-operation has arranged with the Atomic Energy Rosearch Establishment at Harwell and the Centre d'Etudes Nucléaires at Saclay (France) for two international 